\title{
(Micro)-structural comparison between geopolymers, alkali-activated slag cement and Portland cement
}

\author{
I. Lecomte ${ }^{\mathrm{a}, *}$, C. Henrist ${ }^{\mathrm{a}}$, M. Liégeois ${ }^{\mathrm{a}}$, F. Maseri ${ }^{\mathrm{b}}$, A. Rulmont ${ }^{\mathrm{a}}$, R. Cloots ${ }^{\mathrm{a}}$ \\ a SUPRATECS, LCIS, Department of Chemistry, Chemistry Institute B6, University of Liège, Sart-Tilman B-4000 LIEGE, Belgium \\ ${ }^{\mathrm{b}}$ Construction Steel Design Centre (ARCELOR INNOVATION), Boulevard de Colonster B57, Sart-Tilman B-4000 LIEGE, Belgium
}

Received 11 May 2005; received in revised form 2 December 2005; accepted 12 December 2005

\begin{abstract}
Concurrently to research conducted on ordinary Portland cement (PC), new types of binders were developed during the last decades. These are formed by alkali-activation of metakaolin or ground-granulated blast furnace slag (GGBFS) and are named, respectively, geopolymers (GP) or alkali-activated slag (AAS). Four different cementitious materials were synthesised: PC, AAS, GP, and a mix GP-AAS and fully compared about their compositions and (micro)-structures.

X-ray diffraction has revealed the presence of semi-crystalline $\mathrm{C}-\mathrm{S}-\mathrm{H}$ gel binding phase in PC while AAS, GP and GP-AAS are nearly amorphous. Progressive structural changes have been observed between the different samples by means of infrared spectroscopy, ${ }^{29} \mathrm{Si}$ and ${ }^{27} \mathrm{Al}$ magic-angle-spinning nuclear magnetic resonance spectroscopy: there is a polymerisation extent of the (alumino)-silicate framework from PC $\left[\mathrm{SiQ}^{1}\right.$ and $\mathrm{SiQ}^{2}$ units] to $\mathrm{AAS}\left[\mathrm{SiQ}^{2}\right.$ and $\mathrm{SiQ}^{2}(1 \mathrm{Al})$ units] and finally to $\mathrm{GP}^{2} \mathrm{SiQ}^{4}(2 \mathrm{Al})$ and $\mathrm{SiQ}^{4}(3 \mathrm{Al})$ units]. Scanning electron microscopy has shown that GP is a homogeneous matrix while the other materials are composites containing GGBFS grains surrounded by a binding matrix. Energy dispersive X-ray EDX analyses (line scans) have shown the absence of formation of any specific phase at the matrix-grains interfaces.

(C) 2006 Elsevier Ltd. All rights reserved.
\end{abstract}

Keywords: Electron microscopy; Microstructure-final; Spectroscopy; X-ray methods; Cements

\section{Introduction}

The most used and most manufactured cement type is "Portland cement" (PC). It consists of the so-called Portland cement clinker mixed with a few percent of gypsum $\left(\mathrm{CaSO}_{4} \cdot 2 \mathrm{H}_{2} \mathrm{O}\right)$ or anhydrite $\left(\mathrm{CaSO}_{4}\right)$. Portland cement clinker contains four major phases: tricalcium silicate $\left(\mathrm{C}_{3} \mathrm{~S}\right), \beta$-dicalcium silicate $\left(\beta-\mathrm{C}_{2} \mathrm{~S}\right)$, tricalcium aluminate $\left(\mathrm{C}_{3} \mathrm{~A}\right)$, and ferrite solid solution $\left(\mathrm{C}_{2}(\mathrm{~A}, \mathrm{~F})\right)$ (in the cement nomenclature, $\mathrm{C}=\mathrm{CaO}, \mathrm{S}=\mathrm{SiO}_{2}, \mathrm{~A}=\mathrm{Al}_{2} \mathrm{O}_{3}$, $\mathrm{H}=\mathrm{H}_{2} \mathrm{O}, \mathrm{F}=\mathrm{Fe}_{2} \mathrm{O}_{3}, \mathrm{M}=\mathrm{MgO}$ and $\left.\hat{\mathrm{S}}=\mathrm{SO}_{4}\right)$. The main reaction product of Portland cement is a very poorly crystalline calcium silicate hydrate known as $\mathrm{C}-\mathrm{S}-\mathrm{H}$. It is produced by hydration of $\mathrm{C}_{3} \mathrm{~S}$ and $\beta-\mathrm{C}_{2} \mathrm{~S}$ and is often designated as a gel when there are other phases admixed on a sub-micrometre scale. It is generally accepted that the $\mathrm{Ca} / \mathrm{Si}$ molar ratio of $\mathrm{C}-\mathrm{S}-\mathrm{H}$ gel is in the range of $1.5-2$, and in most cases near 1.7. $\mathrm{C}-\mathrm{S}-\mathrm{H}$ gel represents the primary binding phase in Portland cement and

\footnotetext{
* Corresponding author. Tel.: +32 4 3663452; fax: +32 43663413

E-mail address: I.Lecomte@ulg.ac.be (I. Lecomte).
}

controls the strength development of the paste. Great progress has been made in the understanding of the hydration chemistry of Portland cement. ${ }^{1}$ However, at present, the structure of the $\mathrm{C}-\mathrm{S}-\mathrm{H}$ gel is imperfectly known and a lot of ambiguities still remain. What can be said unambiguously is that $\mathrm{C}-\mathrm{S}-\mathrm{H}$ has a layered structure with similarities to the 1.4-nm tobermorite $\left[\mathrm{Ca}_{5} \mathrm{Si}_{6} \mathrm{O}_{16}(\mathrm{OH})_{2} \cdot 8 \mathrm{H}_{2} \mathrm{O}\right.$ or $\left.\mathrm{C}_{5} \mathrm{~S}_{6} \mathrm{H}_{9}\right]$ and/or jennite $\left[\mathrm{Ca}_{9} \mathrm{H}_{2} \mathrm{Si}_{6} \mathrm{O}_{18}(\mathrm{OH})_{8} \cdot 6 \mathrm{H}_{2} \mathrm{O}\right.$ or $\left.\mathrm{C}_{9} \mathrm{~S}_{6} \mathrm{H}_{11}\right] \cdot{ }^{11}$ However, compared to 1.4-nm tobermorite and jennite, $\mathrm{C}-\mathrm{S}-\mathrm{H}$ is mainly amorphous, its $\mathrm{C} / \mathrm{S}$ ratio is more variable and its silicate anion chains are very short (primarily dimers with a lesser amount of pentamers and octamers). ${ }^{12}$

Ground-granulated blast furnace slag (GGBFS) is an amorphous by-product of the steel industry. It has a latent hydraulic reactivity, which can be catalysed by proper activators such as Portland cement clinker, lime, gypsum, and alkali metal hydroxides, carbonates or silicates to form cementitious materials. The main reaction product generally cited for alkali-activated slag is $\mathrm{C}-\mathrm{S}-\mathrm{H}$ gel similar to that found in PC but with lower $\mathrm{Ca} / \mathrm{Si}$ ratios (around 0.7). ${ }^{2-5}$ Some authors have also mentioned the presence of a $\mathrm{Mg}-\mathrm{Al}$ rich phase similar to hydrotalcite 
$\left[\mathrm{Mg}_{6} \mathrm{Al}_{2} \mathrm{CO}_{3}(\mathrm{OH})_{16} \cdot 4 \mathrm{H}_{2} \mathrm{O}\right]$ or a tetracalcium aluminate hydrate phase $(\mathrm{C}, \mathrm{M})_{4} \mathrm{AH}_{13}$. ${ }^{6,7}$

Alkali-activation of aluminosilicates, such as metakaolin or calcined clays, can also produce inorganic binders with excellent physical and chemical properties suitable for building purposes. These are called geopolymers and are widely developing since the last two decades. Aluminosilicates are reacted with aqueous alkaline solutions to activate and promote partial solid dissolution, which is then followed by polycondensation of the dissolved species to form an amorphous aluminosilicate gel and afterwards by the solid-state transformation of the gel. Within the geopolymer research community, the aluminosilicate gel is mainly considered as an amorphous three-dimensional framework of $\mathrm{SiO}_{4}$ and $\mathrm{AlO}_{4}$ tetrahedra randomly interlinked by shared $\mathrm{O}$ atoms. The negatively charged and tetrahedrally coordinated $\mathrm{Al}$ atoms inside the network are charge-balanced by alkali metal cations coming from the activating solution. Geopolymeric binders have thus similar chemical composition as natural zeolitic materials but without the extensive crystalline zeolitic structure. $^{8-10}$

Ordinary Portland cement, alkali-activated slag cement, and geopolymers represent three different cementitious materials with their own characteristics and properties. These three types of materials have been extensively considered in the last 10 years. However, only specific studies about one type of cement have been considered. Up to now, no complete research has established precise relationships between geopolymers and the other two types of Ca-based binders.

The purpose of this study is a detailed comparison between geopolymers, alkali-activated slag cement and ordinary Portland cement regarding to the chemical composition, the crystal structure, and the microstructure. For the first time, differences and similarities between these three inorganic binders were highlighted by means of XRD analysis, IR spectroscopy, ${ }^{27} \mathrm{Al}$ and ${ }^{29} \mathrm{Si}$ MAS-NMR spectroscopy, and SEM-EDX analysis.

\section{Experimental procedures}

\subsection{Reacting materials}

Metakaolin, ground-granulated blast furnace slag (GGBFS), and Portland clinker were supplied by the Construction Steel Design Centre (ARCELOR INNOVATION, Liège) in Belgium. The chemical composition of both metakaolin and GGBFS is given in Table 1. Potassium metasilicate was purchased from PQ Europe (Maastricht, The Netherlands) and contains $11.1 \mathrm{wt} . \%$ of $\mathrm{K}_{2} \mathrm{O}, 23.9$ wt. $\%$ of $\mathrm{SiO}_{2}$, and 65 wt.\% of $\mathrm{H}_{2} \mathrm{O}$. Deionised water and analytical grade $\mathrm{KOH}$ were used throughout all experiments.
Table 1

Chemical composition of the starting materials

\begin{tabular}{lll}
\hline Components (wt.\%) & Metakaolin & Ground-granulated blast furnace slag \\
\hline $\mathrm{SiO}_{2}$ & 55.57 & $33-38$ \\
$\mathrm{CaO}$ & & $38-43$ \\
$\mathrm{Al}_{2} \mathrm{O}_{3}$ & 42.43 & $9-13$ \\
$\mathrm{MgO}$ & & $7-12$ \\
$\mathrm{Fe}$ & $0.1-15$ \\
$\mathrm{MnO}$ & $0-2$ \\
$\mathrm{~S}$ & $0-2.5$ \\
$\mathrm{TiO}_{2}$ & $0.3-0.9$ \\
$\mathrm{~K}_{2} \mathrm{O}$ & $0-0.8$ \\
$\mathrm{H}_{2} \mathrm{O}$ & $<20$ \\
\hline
\end{tabular}

\subsection{Synthesis}

Geopolymer (GP) samples were synthesised by adding metakaolin to a solution of alkaline activators. This alkaline solution was prepared by the dissolution of potassium hydroxide pellets in a potassium metasilicate solution to obtain a molar oxide ratio $\mathrm{K}_{2} \mathrm{O} / \mathrm{SiO}_{2}$ equal to 0.68 . A few millilitres of water were added at the same time to the paste to achieve a suitable workability. Alkali-activated slag (AAS) samples were produced by mixing GGBFS with the same alkaline solution (potassium metasilicate and potassium hydroxide, $\mathrm{K}_{2} \mathrm{O} / \mathrm{SiO}_{2}=0.68$ ) using a minimal amount of water (a few millilitres). The alkaline solution was also added to a mixture of metakaolin and GGBFS in order to prepare samples that contain both a geopolymeric phase and an alkali-activated slag phase (the GP-AAS samples). Portland cement (PC) samples were obtained by mixing Portland clinker CEM II (clinker + fly ash + GGBFS) with deionised water to achieve a water to cement ratio equal to 0.35 .

After mixing for $5 \mathrm{~min}$, all pastes were poured in hermetic polyethylene molds and allowed to cure at room temperature for more than 28 days. The amounts of the components used to synthesise the different samples (wt.\%) are given in Table 2.

\subsection{Experimental techniques}

Infrared spectra were recorded on a Perkin-Elmer Fourier transform infrared (FTIR) $1720 \times$ spectrometer using the $\mathrm{KBr}$ pellet technique $(3.5 \mathrm{mg}$ of powder sample mixed with $800 \mathrm{mg}$ of $\mathrm{KBr}$ ).

X-ray powder diffraction data were collected using a Siemens D5000 powder diffractometer (Karlsruhe, Germany) with Ni-filtered $\mathrm{Cu} \mathrm{K} \alpha$ radiation $(40 \mathrm{kV} ; 50 \mathrm{~mA})$.

${ }^{29} \mathrm{Si}$ and ${ }^{27} \mathrm{Al}$ solid-state MAS-NMR spectroscopy was carried out at $9.04 \mathrm{~T}$ using a Bruker Avance DSX 400WB

Table 2

Composition of the different samples: wt.\% of the reactants

\begin{tabular}{|c|c|c|c|c|c|}
\hline Samples & Metakaolin & GGBFS & Portland clinker CEM II & Alkaline solution $\mathrm{K}_{2} \mathrm{O} / \mathrm{SiO}_{2}=0.68$ & $\mathrm{H}_{2} \mathrm{O}$ \\
\hline GP & 44.64 & & & 44.64 & 10.72 \\
\hline GP-AAS & 25.24 & 37.87 & & 25.27 & 11.63 \\
\hline AAS & & 66.51 & & 28.50 & 4.99 \\
\hline $\mathrm{PC}$ & & & 74.22 & & 25.78 \\
\hline
\end{tabular}


spectrometer (Karlsruhe, Germany) operating at 79.5 and 104.27 MHz for the ${ }^{29} \mathrm{Si}$ and ${ }^{27} \mathrm{Al}$ resonance frequencies, respectively. ${ }^{29} \mathrm{Si}$ and ${ }^{27} \mathrm{Al}$ MAS-NMR spectra (spinning rate of $10 \mathrm{kHz}$ ) were recorded with 7.8 - and $3-\mu$ s simple pulse and with 10- and 0.3-s delay, respectively. The number of transients collected is 1000 for ${ }^{27} \mathrm{Al}$ and 1200 for ${ }^{29} \mathrm{Si}$. Chemical shifts are referenced to tetramethylsilane for the ${ }^{29} \mathrm{Si}$ nuclei and to $\mathrm{AlCl}_{3}(1 \mathrm{M})$ for the ${ }^{27} \mathrm{Al}$ nuclei.

Scanning electron microscopy (SEM) and energy dispersive $\mathrm{X}$-ray (EDX) micro-analysis were performed on a Philips ESEM XL30 FEG (Eindhoven, The Netherlands) with an accelerating voltage of $10-15 \mathrm{kV}$. All cementitious samples were enclosed in epoxy resin and polished with $\mathrm{SiC}$ papers and diamond paste; the polished cross-sections were then gold-coated before observation.

\section{Results and discussions}

\subsection{X-ray diffraction analysis}

X-ray patterns of geopolymer sample (GP), geopolymer-alkali-activated slag sample (GP-AAS), alkaliactivated slag sample (AAS), and Portland cement sample (PC) are presented in Fig. 1(A-D), respectively.

The PC sample is mainly amorphous in view of the

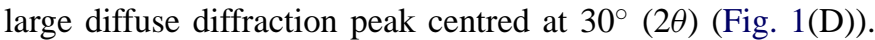

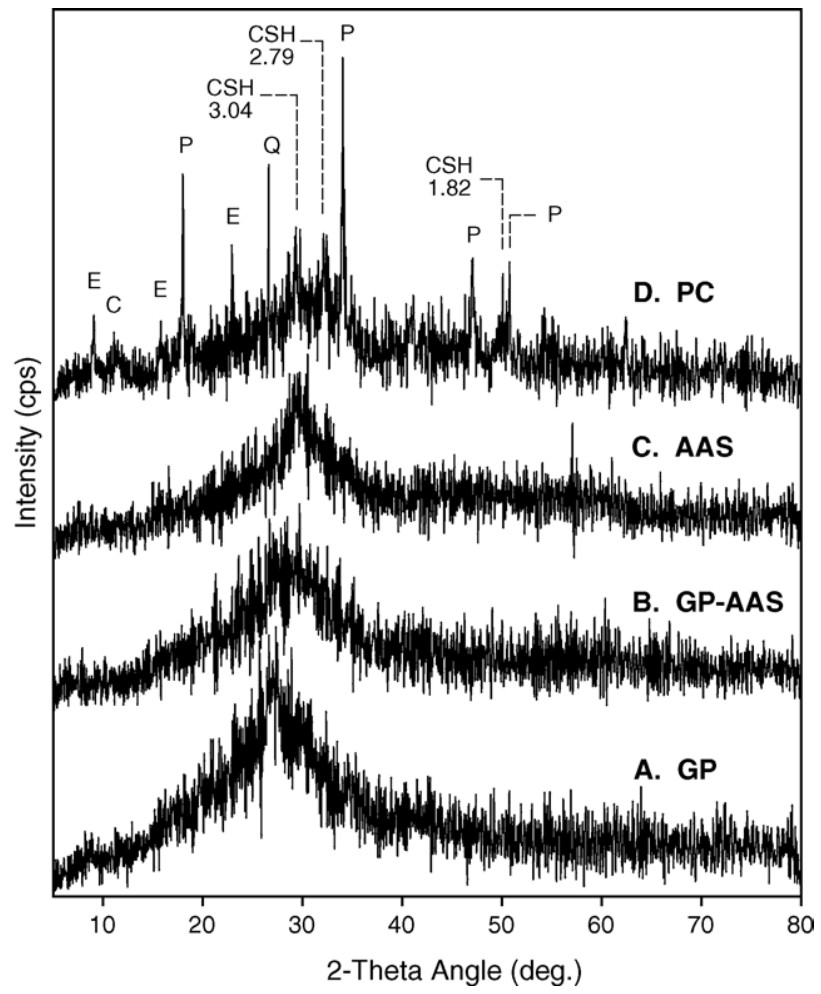

Fig. 1. X-ray powder patterns of (A) GP sample, (B) GP-AAS sample, (C) AAS sample, and (D) PC sample [E = ettringite $\left(\mathrm{Ca}_{6} \mathrm{Al}_{2}\left(\mathrm{SO}_{4}\right)_{3}(\mathrm{OH})_{12} \cdot 26 \mathrm{H}_{2} \mathrm{O}\right), \mathrm{PDF}$ no. 41-1451; $\mathrm{P}=$ portlandite $\left(\mathrm{Ca}(\mathrm{OH})_{2}\right), \mathrm{PDF}$ no. 44-1481; $\mathrm{CSH}=$ calcium silicate hydrate $\left(1.5 \mathrm{CaO} \cdot \mathrm{SiO}_{2} \cdot x \mathrm{H}_{2} \mathrm{O}\right), \mathrm{PDF}$ no. 33-0306; $\mathrm{Q}=$ quartz $\left(\mathrm{SiO}_{2}\right), \mathrm{PDF}$ no. 85-1780; $\mathrm{C}=$ calcium aluminate hydrate $\left(\mathrm{Ca}_{4} \mathrm{Al}_{2} \mathrm{O}_{7} \cdot 13 \mathrm{H}_{2} \mathrm{O}\right.$ or $\left.\mathrm{C}_{4} \mathrm{AH}_{13}\right)$, PDF no. 11-0203].
However, for the PC sample only, the X-ray pattern also shows some sharper reflection peaks corresponding to ettringite $\left[\mathrm{Ca}_{6} \mathrm{Al}_{2}\left(\mathrm{SO}_{4}\right)_{3}(\mathrm{OH})_{12} \cdot 26 \mathrm{H}_{2} \mathrm{O}\right]$, portlandite $\left[\mathrm{Ca}(\mathrm{OH})_{2}\right]$, quartz $\left(\mathrm{SiO}_{2}\right)$, and also to calcium silicate hydrate gel $\left[(\mathrm{CaO})_{x} \cdot \mathrm{SiO}_{2} \cdot\left(\mathrm{H}_{2} \mathrm{O}\right)_{y}\right]$, respectively. $\mathrm{C}-\mathrm{S}-\mathrm{H}$ gel is characterised by three diffraction peaks at $3.04,2.79$, and $1.82 \AA$ (representing the (2 20), (400), and (0 40) reflections of 1.1-nm tobermorite, respectively), which are reasonably well visible on the X-ray pattern of PC sample (Fig. 1(D)). ${ }^{1,13}$

As shown by the diffuse halo diffraction peak centred around $30^{\circ}(2 \theta)$, GP, GP-AAS, and AAS samples (Fig. 1(A-C), respectively) are completely amorphous with clearly a lack of longrange order. The halo undergoes progressively a slight shift towards greater angle values from about $27^{\circ}(2 \theta)$ for GP sample to about $31^{\circ}(2 \theta)$ for PC sample.

Although many authors have found that the major hydration products of AAS are $\mathrm{C}-\mathrm{S}-\mathrm{H}$ gel phases, 3,4 X-ray patterns of GP-AAS and AAS samples do not allow such a conclusion. Moreover, there is no trace of a $\mathrm{Mg}, \mathrm{Al}$ rich phase related to the naturally occurring mineral hydrotalcite $\left[\mathrm{Mg}_{6} \mathrm{Al}_{2}\left(\mathrm{CO}_{3}\right)(\mathrm{OH})_{16} \cdot 4 \mathrm{H}_{2} \mathrm{O}\right]$ and of a tetracalcium aluminate hydrate phase such as $(\mathrm{C}, \mathrm{M})_{4} \mathrm{AH}_{13}$, despite these are also referred as current hydration products of AAS. ${ }^{6}$

On the other hand, the X-ray pattern of GP sample is very similar to that previously published for geopolymer materials. ${ }^{8-10}$

$\mathrm{X}$-ray diffraction allows only to say that absolutely no crystalline or semi-crystalline phase is formed in GP, GP-AAS, and AAS materials, which are more amorphous than the $\mathrm{C}-\mathrm{S}-\mathrm{H}$ gel phase occurring in ordinary Portland cement, with a lack of long-range order.

\subsection{Infrared analysis}

Fig. 2(A-D) display infrared spectra of geopolymer sample (GP), geopolymer-alkali-activated slag sample (GP-AAS), alkali-activated slag sample (AAS), and Portland cement sample (PC), respectively. These spectra are very comparable to those previously published for each type of sample. ${ }^{2,8,15}$

Infrared spectra of the four samples are rather similar, presenting analogous absorption bands. All show bands at 3440 and $1650 \mathrm{~cm}^{-1}$, respectively, related to $\mathrm{O}-\mathrm{H}$ stretching and bending modes of molecular water; and also near $1000 \mathrm{~cm}^{-1}$ and at $450 \mathrm{~cm}^{-1}$ due to anti-symmetric $\mathrm{Si}-\mathrm{O}(\mathrm{Al})$ stretching vibrations $\left(v_{3}\right)$ and to in-plane $\mathrm{Si}-\mathrm{O}$ bending vibrations $\left(v_{2}\right)$ in $\mathrm{SiO}_{4}$ tetrahedra, respectively. Nevertheless, some differences are observed. Only the infrared spectrum of the PC sample (Fig. 2(D)) displays a sharp band at $3640 \mathrm{~cm}^{-1}$ associated to $\mathrm{O}-\mathrm{H}$ stretching vibrations of portlandite $\left[\mathrm{Ca}(\mathrm{OH})_{2}\right]$; a weak band at $1110 \mathrm{~cm}^{-1}$ and a sharp peak at $660 \mathrm{~cm}^{-1}$ corresponding, respectively, to $\mathrm{S}-\mathrm{O}_{4}$ stretching mode $\left(v_{3}\right)$ and out-ofplane bending mode $\left(v_{4}\right)$ of ettringite; and also a shoulder near $530 \mathrm{~cm}^{-1}$ probably due to out-of-plane $\mathrm{Si}-\mathrm{O}$ bending vibrations $\left(v_{4}\right){ }^{16,17}$

All samples with the exception of the GP sample contain carbonate species pointed out by the presence of the large absorption band near $1450 \mathrm{~cm}^{-1}$ and of the small one at $870 \mathrm{~cm}^{-1}$, 


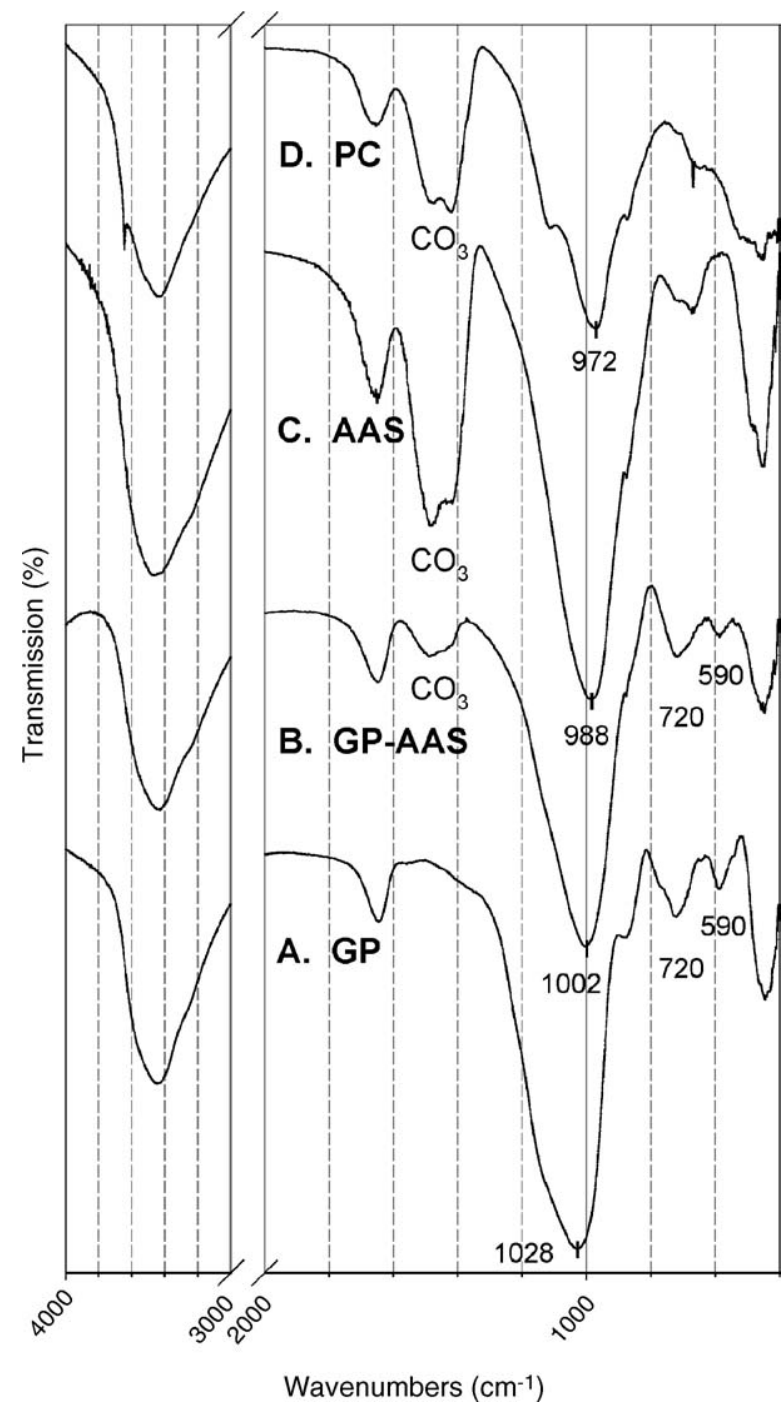

Fig. 2. Infrared spectra of (A) GP sample, (B) GP-AAS sample, (C) AAS sample, and (D) PC sample.

respectively, related to anti-symmetric stretching $\left(v_{3}\right)$ and outof-plane bending $\left(v_{2}\right)$ modes of $\mathrm{CO}_{3}{ }^{2-}$ ions. ${ }^{15,16}$ This observation suggests that geopolymers are less sensitive to atmospheric carbonation than ordinary Portland cement or alkali-activated slag cement.

The principal band associated with the $\mathrm{Si}-\mathrm{O}(\mathrm{Al})$ stretching vibrations in $\mathrm{SiO}_{4}$ tetrahedra near $1000 \mathrm{~cm}^{-1}$ is very broad particularly for the GP, GP-AAS, and AAS samples. It confirms that these materials are more disordered than Portland cement. The lack of a sharp feature is indicative of the wide distribution of the $\mathrm{SiQ}^{n}(\mathrm{mAl})$ units occurring in these structures. The $\mathrm{Si}-\mathrm{O}$ stretching modes for the $\mathrm{SiQ}^{n}$ units show infrared absorption bands localised around 1200,1100, 950, 900, and $850 \mathrm{~cm}^{-1}$ for $n=4,3,2,1$, and 0 , respectively. ${ }^{18}$ These values shift to lower wavenumbers when the degree of silicon substitution by aluminium in the second coordination sphere increases, as a consequence of the weaker $\mathrm{Al}-\mathrm{O}$ bonds.

In Fig. 2, it appears that this $\mathrm{Si}-\mathrm{O}$ stretching band shifts progressively towards greater wavenumbers from $970 \mathrm{~cm}^{-1}$ for
PC sample (Fig. 2(D)) to $1030 \mathrm{~cm}^{-1}$ for GP sample (Fig. 2(A)) as the $\mathrm{Si} / \mathrm{Al}$ molar ratio is decreasing (4 to 1.8 ). These results indicate a distribution of the $\mathrm{Q}^{n}$ units centred around $\mathrm{Q}^{1}$ and $\mathrm{Q}^{2}$ units for Portland cement sample, while the shift to higher wavenumbers points out the presence of more polymerised units such as $\mathrm{Q}^{2}$ and $\mathrm{Q}^{3}$ units for alkali-activated slag sample and $\mathrm{Q}^{4}$ units for geopolymer sample.

In the structure of highly polymerised silicates, silicooxygen rings occur most frequently with three, four and six members. The typical bands of the ring system (pseudo-lattice vibrations) are located mainly in the middle IR spectra in the range $800-500 \mathrm{~cm}^{-1}: 720-700 \mathrm{~cm}^{-1}$ for 3-membered rings, $650 \mathrm{~cm}^{-1}$ for four-membered rings and $620-600 \mathrm{~cm}^{-1}$ in the case of sixmembered rings. ${ }^{19,20}$

Two absorption bands at 720 and $590 \mathrm{~cm}^{-1}$ appear in the case of GP and GP-AAS samples (Fig. 2(A and B)). The higher band would be related to the symmetric stretching vibrations of the $\mathrm{Si}-\mathrm{O}-\mathrm{Si}(\mathrm{Al})$ bridges. The next band at $590 \mathrm{~cm}^{-1}$ would correspond to the cyclosilicates vibrations; its intensity increases with the aluminium and silicon contents (Table 3 ). The analogy between the IR spectra of the GP sample and $\alpha$-cristobalite $\mathrm{SiO}_{2}$ (the low temperature tetragonal phase) allows to suggest a structural similitude with interconnected cyclohexasilico-aluminate rings. ${ }^{21}$ The width of this $590 \mathrm{~cm}^{-1}$ band can be related to disorder and/or deformation of the six-membered rings.

In the AAS spectrum, the absorption band around $700 \mathrm{~cm}^{-1}$ suggests the formation of smaller three-membered rings and a less polymerised structure. ${ }^{20}$

Finally, GP sample and GP-AAS sample show very similar infrared spectra; GP-AAS spectrum marks a transition between GP spectrum and AAS spectrum. The spectrum of AAS sample is slightly different with an intermediate shape between PC sample and GP sample. It suggests that the structure of alkali-activated slag phases is a transition between the structures of ordinary Portland cement and

Table 3

Composition of the matrix in GP, GP-AAS, AAS, and PC samples; and of the GGBFS particles in GP-AAS, AAS, and PC samples, detected by SEM/EDX

\begin{tabular}{llccc}
\hline $\begin{array}{l}\text { Elements (oxides) } \\
\text { (wt.\%) }\end{array}$ & GP sample & $\begin{array}{l}\text { GP-AAS } \\
\text { sample }\end{array}$ & AAS sample & PC sample \\
\hline Matrix & & 3.5 & 4 & \\
$\mathrm{MgO}$ & 27 & 22 & 8.8 & 5 \\
$\mathrm{Al}_{2} \mathrm{O}_{3}$ & 58 & 49.8 & 43 & 73 \\
$\mathrm{SiO}_{2}$ & 14 & 8.9 & 14.4 & 1.6 \\
$\mathrm{~K}_{2} \mathrm{O}$ & & 16 & 29.2 & 53 \\
$\mathrm{CaO}$ & - & 0.3 & 0.7 & 1.7 \\
$\mathrm{Ca} / \mathrm{Si}(\mathrm{mol})$ & 1.8 & 1.9 & 4.1 & 4.0 \\
$\mathrm{Si} / \mathrm{Al}(\mathrm{mol})$ & & & & \\
$\mathrm{Particles}$ & & 7.19 & 7.3 & 8 \\
$\mathrm{MgO}$ & & 12.6 & 11.9 & 11.8 \\
$\mathrm{Al} \mathrm{O}_{3}$ & & 39.6 & 39 & 37.5 \\
$\mathrm{SiO}$ & & 0.9 & 1.09 & 0.51 \\
$\mathrm{~K}_{2} \mathrm{O}$ & & 40 & 40.7 & 42 \\
$\mathrm{CaO}$ & & 1.1 & 1.1 & 1.2 \\
$\mathrm{Ca} / \mathrm{Si}$ (mol) & & 2.7 & 2.8 & 2.7 \\
$\mathrm{Si} / \mathrm{Al}$ (mol) & & & & \\
\hline
\end{tabular}




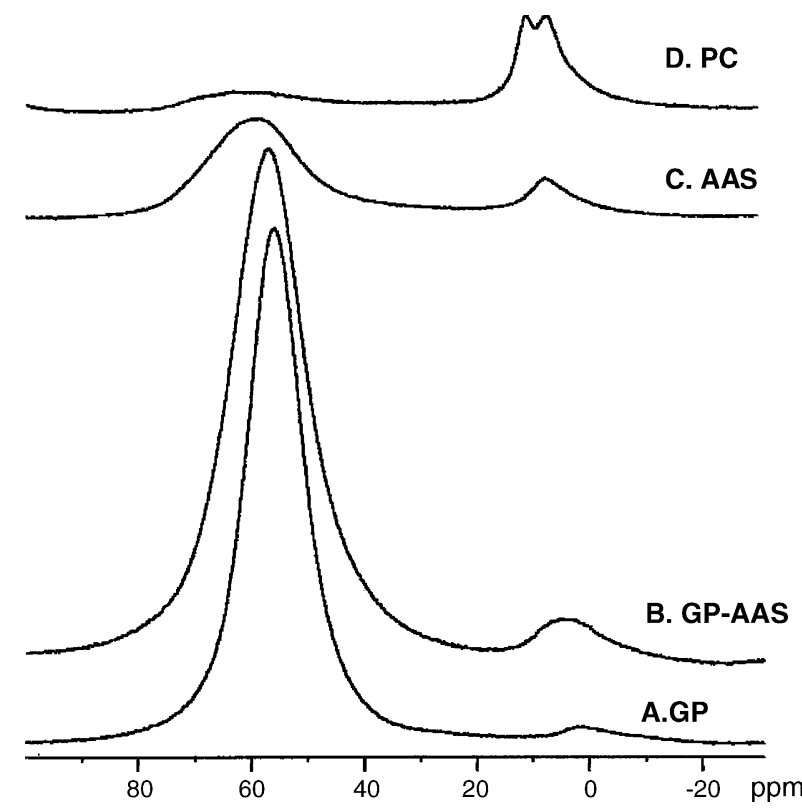

Fig. 3. ${ }^{27}$ Al MAS-NMR spectra of (A) GP sample, (B) GP-AAS sample, (C) AAS sample, and (D) PC sample.

geopolymers while the incorporation of a non-negligible quantity of GGBFS (around $40 \mathrm{wt} . \%$ ) in a geopolymeric binder seems to have no fundamental influence on the final structure of geopolymers with regard to the similarity between the infrared spectra (above $400 \mathrm{~cm}^{-1}$ ) of GP sample and GP-AAS sample.

\section{3. ${ }^{29}$ Si and ${ }^{27}$ Al MAS-NMR analysis}

${ }^{29} \mathrm{Si}$ and ${ }^{27} \mathrm{Al}$ MAS-NMR appear as suitable techniques to probe structural features of geopolymers, alkali-activated slag cement, and Portland cement. Actually, determination of the aluminium coordination number with oxygen (four, five, or six) is possible with ${ }^{27} \mathrm{Al}$ MAS-NMR ${ }^{22}$ and ${ }^{29} \mathrm{Si}$ MAS-NMR allows the differentiation between the different $\mathrm{SiQ}^{n}(\mathrm{mAl})$ structural units. $^{23}$

${ }^{27}$ Al MAS-NMR spectra of GP, GP-AAS, AAS, and PC samples are shown on Fig. 3(A-D), respectively.

In the ${ }^{27} \mathrm{Al}$ MAS-NMR spectrum of PC sample (Fig. 3(D)), the very large and weak band centred approximately at $64 \mathrm{ppm}$ is assigned to tetrahedrally coordinated $\mathrm{Al}$ incorporated in the $\mathrm{C}-\mathrm{S}-\mathrm{H}$ gel, while the spectral range for octahedrally coordinated $\mathrm{Al}$ displays two sharper bands at 12 and $8 \mathrm{ppm}$. The first sharp resonance originates from ettringite $\left(\mathrm{C}_{6} \mathrm{AS}_{3} \mathrm{H}_{32}\right)$ (reported to have an isotropic chemical shift of $13.1 \mathrm{ppm}$ ) that has already been detected by X-ray diffraction (Fig. 1(D)). The second one at $8 \mathrm{ppm}$ could correspond to the isotropic chemical shift of the monosulfate phase, $\mathrm{C}_{4} \mathrm{AS} \mathrm{SH}_{12}\left(\delta_{\text {iso }}=11.8 \mathrm{ppm}\right)$, and of the tetracalcium aluminate hydrate phase, $\mathrm{C}_{4} \mathrm{AH}_{13}$ $\left(\delta_{\text {iso }}=10.2 \mathrm{ppm}\right)$ (the chemical shift difference can be due to a large amount of disorder as these two phases are unobserved by XRD). ${ }^{24,25}$

${ }^{27} \mathrm{Al}$ MAS-NMR spectrum of AAS sample is very different (Fig. 3(C)); it shows a major content of tetrahedrally coordinated
$\mathrm{Al}$ in connection with the large band centred at $59 \mathrm{ppm}$ and a lower amount of octahedrally coordinated $\mathrm{Al}$ related to the band at $8 \mathrm{ppm}$. The later resonance is possibly assigned to a tetracalcium aluminate hydrate phase $\left[(\mathrm{C}, \mathrm{M})_{4} \mathrm{AH}_{13}\right]$ or to a $\mathrm{Mg}-\mathrm{Al}$ rich phase similar to hydrotalcite $\left[\mathrm{Mg}_{6} \mathrm{Al}_{2} \mathrm{CO}_{3}(\mathrm{OH})_{16} \cdot 4 \mathrm{H}_{2} \mathrm{O}\right]$, often referred as reaction products of alkali-activated slag. ${ }^{7}$ This phase, substantially disordered, would be formed consequently to the alkaline activation of GGBFS, as ${ }^{27} \mathrm{Al}$ MAS-NMR spectrum of raw GGBFS displays only a large resonance near $57 \mathrm{ppm}$.

GP and GP-AAS samples have very similar ${ }^{27}$ Al MAS-NMR spectra. Both show a well-resolved resonance at 56-57 ppm due to $\mathrm{Al}$ in four-fold coordination and a light hump in the base line around 2-5 ppm, especially for GP-AAS sample. This later is associated to $\mathrm{Al}$ in octahedral coordination and is certainly unreacted aluminium from metakaolin. ${ }^{8}$ The bands associated to $\mathrm{Al}$ in four-fold coordination have very close chemical shifts (56-57 ppm) to that of AAS sample (59 ppm), which shows similar chemical environments of Al(IV) in GP, GP-AAS, and AAS samples.

The comparison between ${ }^{27}$ Al MAS-NMR spectra of the four samples highlights three general continuous evolutions from Portland cement to geopolymers:

1. An increase of the total resonance intensities consistent with a corresponding raise of the samples $\mathrm{Al}$ content.

2. An increase of the tetrahedrally coordinated $\mathrm{Al}$ content and a corresponding decrease for $\mathrm{Al}$ in six-fold coordination.

3. An increase in the polymerisation degree of the aluminosilicate framework as the maximum of the $\mathrm{Al}(\mathrm{IV})$ peak moves from $64 \mathrm{ppm}$ for $\mathrm{PC}$ sample $\left(\mathrm{AlQ}^{2}(2 \mathrm{Si})\right.$ or $\mathrm{AlQ}^{3}(3 \mathrm{Si})$ structural units) to $56 \mathrm{ppm}$ for $\mathrm{GP}$ sample $\left(\mathrm{AlQ}^{4}(4 \mathrm{Si})\right.$ structural unit).

${ }^{29} \mathrm{Si}$ MAS-NMR spectra of GP, GP-AAS, AAS, and PC samples are shown on Fig. 4(A-D), respectively.

Three major environments can be deduced from the ${ }^{29} \mathrm{Si}$ MAS-NMR spectrum of PC sample. The weaker is characterised by a large band centred approximately at $-73 \mathrm{ppm}$ arising from raw Portland cement clinker. The two other main resonances appear at approximately -80 and $-86 \mathrm{ppm}$ and originate from the $\mathrm{SiQ}^{1}$ (disilicates or chain end groups) and $\mathrm{SiQ}^{2}$ (middle groups in chains) units, respectively. ${ }^{24}$

${ }^{29}$ Si MAS-NMR spectrum of AAS sample (Fig. 4(C)) shows some non-negligible differences compared to that of PC sample. It displays only two main peaks, the most important resonates at $-86 \mathrm{ppm}$ and the second one appears at $-83 \mathrm{ppm}$. These have been previously assigned, respectively, to $\mathrm{SiQ}^{2}$ and $\mathrm{SiQ}^{2}(1 \mathrm{Al})$ units by a lot of authors who published similar spectra for alkaliactivated slags. ${ }^{2,3,5,7,26}$ So, most of the silicate tetrahedra are chain mid-members and important Al substitution for Si occurs in the silicate chains. The general characteristic of the AAS sample spectrum compared to the PC sample is a shift towards more negative chemical shifts, which reflects significantly longer aluminosilicate chains than in Portland cement.

GP-AAS sample has a slightly different ${ }^{29} \mathrm{Si}$ MAS-NMR spectrum (Fig. 4(B)) compared to those of AAS and PC samples. 


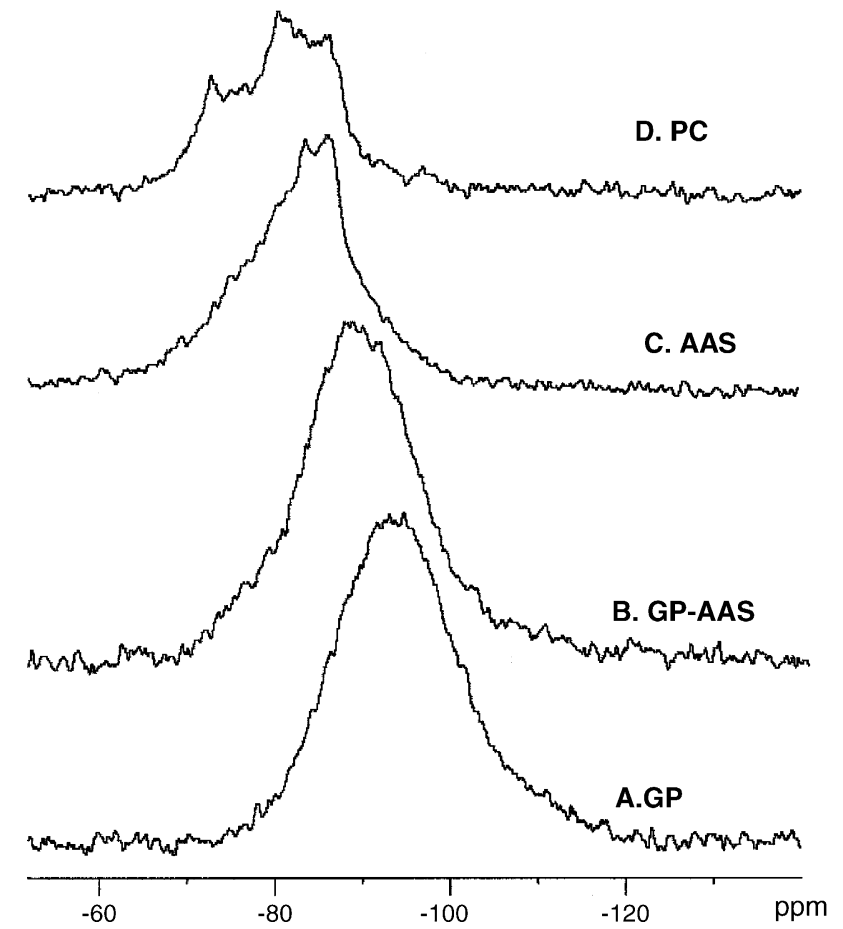

Fig. 4. ${ }^{29} \mathrm{Si}$ MAS-NMR spectra of (A) GP sample, (B) GP-AAS sample, (C) AAS sample, and (D) PC sample.

No distinct peak can be distinguished but only a single broad resonance characteristic of amorphous material containing a range of slightly different environments. The peak is centred approximately at $-89 \mathrm{ppm}$, consistent with chain branching sites $\left(\mathrm{SiQ}^{3}\right.$ units) and three-dimensional cross-linked sites ( $\mathrm{SiQ}^{4}$ units), both with substantial $\mathrm{Al}$ substitution for $\mathrm{Si}^{8}$

${ }^{29} \mathrm{Si}$ MAS-NMR spectrum of GP sample is very similar to that of GP-AAS sample (Fig. 4(A)). The only difference lies in the position of the peaks, whose maxima are localised at $-89 \mathrm{ppm}$ for GP-AAS sample and at $-95 \mathrm{ppm}$ for GP sample. Geopolymer materials are thus characterised by a highly polymerised structure composed principally of threedimensional cross-linked sites such as $\mathrm{SiQ}^{4}(2 \mathrm{Al})$ and $\mathrm{SiQ}^{4}(3 \mathrm{Al})$ units. ${ }^{9,10}$

In summary, Portland cement is composed mainly of $\mathrm{SiQ}^{1}$ and $\mathrm{SiQ}^{2}$ species, which is consistent with the models proposed previously for the $\mathrm{C}-\mathrm{S}-\mathrm{H}$ gel. In these models, silicate groups organize in linear finite chains of "dreierketten" structure (principally dimers and also some pentamers and octamers). In alkali-activated slag, $\mathrm{C}-\mathrm{S}-\mathrm{H}$ gel is formed by longer chains whereas ${ }^{29} \mathrm{Si}$ MAS-NMR spectrum shows mainly chain midmember sites [ $\mathrm{SiQ}^{2}$ and $\left.\mathrm{SiQ}^{2}(1 \mathrm{Al})\right]$. On the contrary, geopolymers contain essentially three-dimensional cross-linked sites $\left[\mathrm{SiQ}^{4}(2 \mathrm{Al})\right.$ and $\left.\mathrm{SiQ}^{4}(3 \mathrm{Al})\right]$, which reflects a highly polymerised structural aluminosilicate framework. Comparison between ${ }^{29} \mathrm{Si}$ MAS-NMR spectra of GP and GP-AAS samples shows that the incorporation of GGBFS in a geopolymer phase does not cause any significant structural change except a slight framework depolymerisation.

The above results are in complete agreement with the conclusions obtained from the infrared and ${ }^{27} \mathrm{Al}$ MAS-NMR spectroscopies; a continuous increase of the degree of polymerisation from Portland cement to alkali-activated slag and to geopolymers.
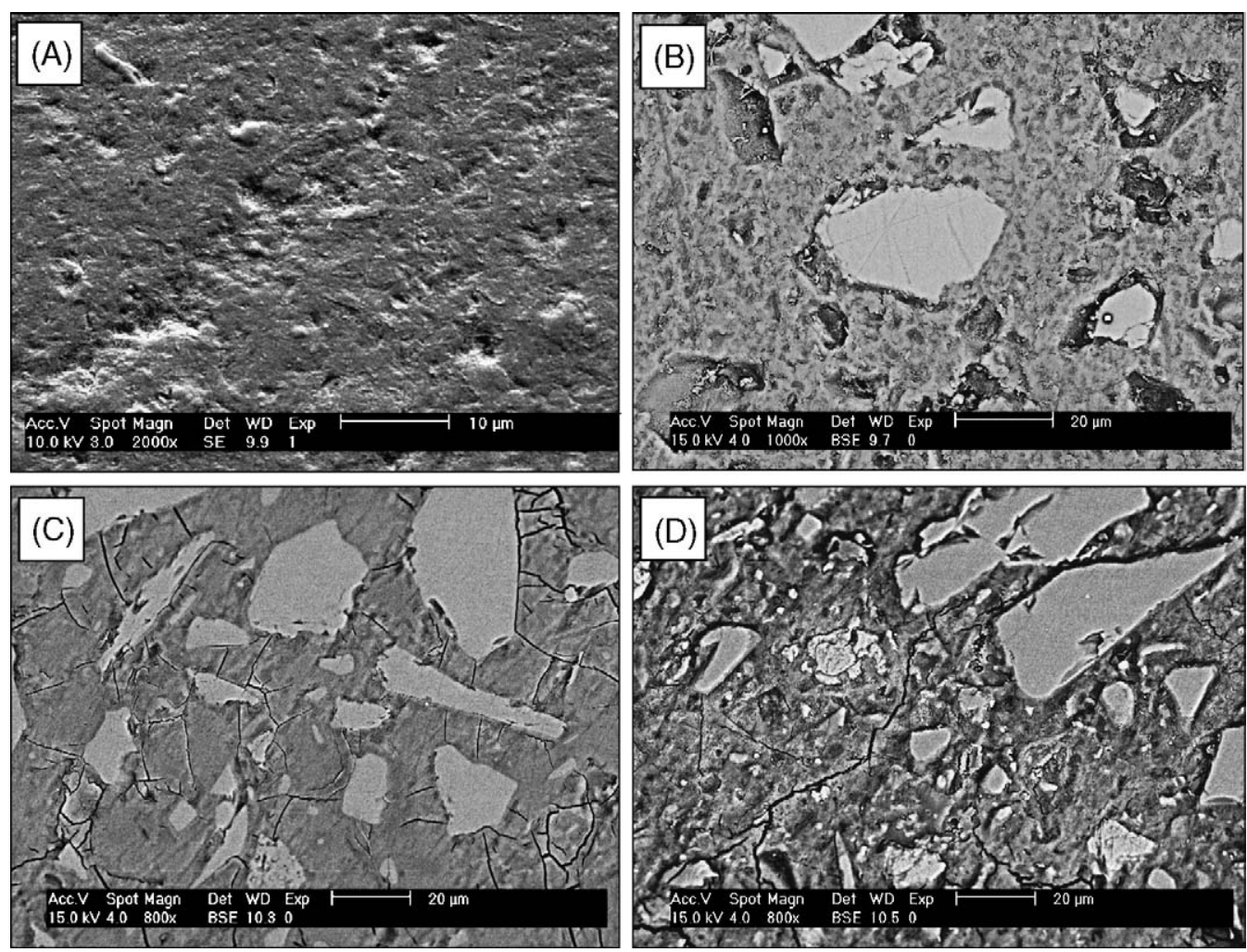

Fig. 5. SEM image of GP sample (A), GP-AAS sample (B), AAS sample (C), and PC sample (D). 


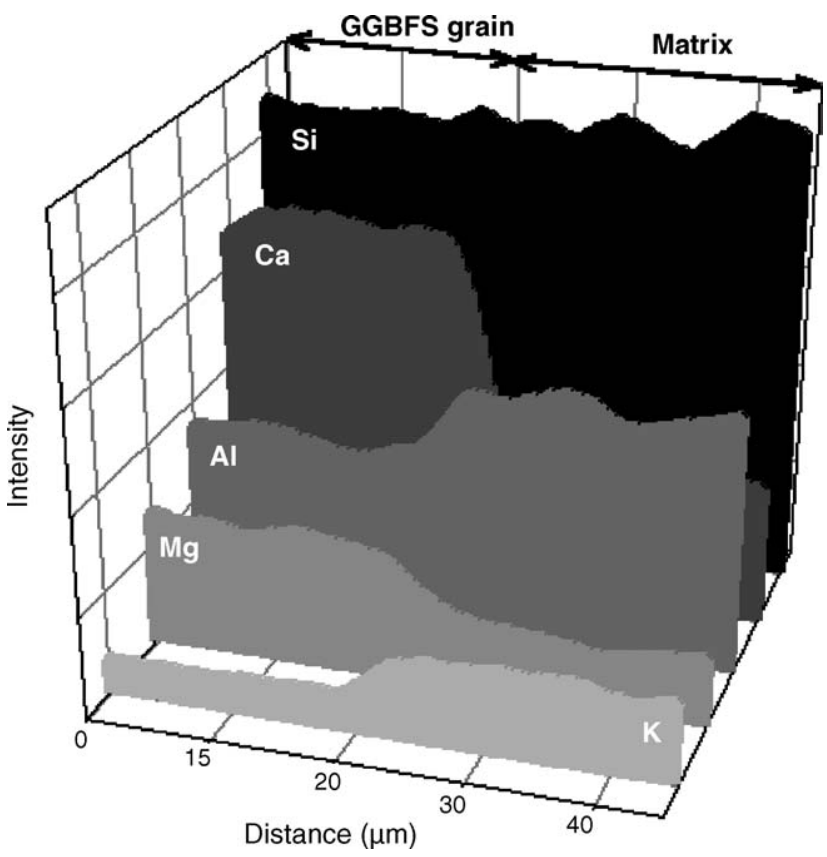

Fig. 6. SEM/EDX line scans from a GGBFS grain to the binding matrix in GP-AAS sample.

\subsection{SEM analysis}

The micrographs of GP, GP-AAS, AAS, and PC samples are shown on Fig. 5(A-D), respectively.

GP micrograph displays a very homogeneous binding matrix without aggregate. On the contrary, GP-AAS, AAS, and PC samples are more heterogeneous. Their micrographs show particles of various shapes and sizes surrounded by a cementitious matrix. GP and GP-AAS materials show absolutely no crack, in opposi-

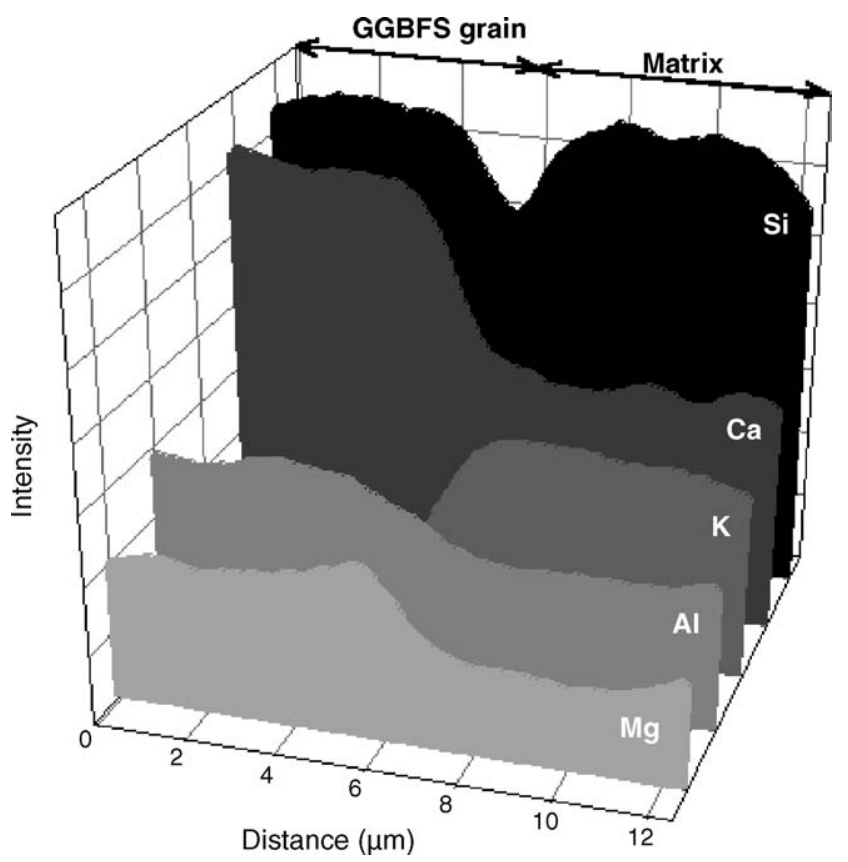

Fig. 7. SEM/EDX line scans from a GGBFS grain to the binding matrix in AAS sample. tion to PC sample and especially to AAS sample. The cracks are running in the binding matrix between the slag grains, but they never pass through them and they are generally not located at the grain-matrix interface either. No reaction zone is observed at the interface between the grains and the matrix around the particles. The cementitious matrix in GP-AAS and AAS samples displays a vitreous aspect, more homogeneous than in PC sample.

Energy dispersive X-ray (EDX) analyses have been performed to determine the composition of the matrix and of the particles. The results are listed in Table 3 , where each value is the mean of five measurements realised either in the matrix (top of the Table 3) or in the particles (bottom of the Table 3). In view of their composition, all the particles are GGBFS grains. GP matrix contains only $\mathrm{Si}, \mathrm{Al}$, and $\mathrm{K}$ arising from the dissolution of metakaolin in the presence of $\mathrm{KOH}$ and sodium metasilicate. Consequently to the incorporation of GGBFS, GP-AAS matrix contains also $\mathrm{Mg}$ and $\mathrm{Ca}$ that may only result from the partial dissolution of GGBFS particles. This confirms previous results suggesting that smaller GGBFS grains react totally while the larger ones react partially with alkaline activators and contribute to the formation of the binding matrix of the composite. ${ }^{8}$ In AAS sample, GGBFS also dissolves partially and contributes to the binding phase in view of the presence of $\mathrm{Mg}, \mathrm{Al}$, and $\mathrm{Ca}$ in the AAS matrix. PC matrix contains essentially $\mathrm{Ca}$ and $\mathrm{Si}$ with a $\mathrm{Ca} / \mathrm{Si}$ molar ratio equal to 1.7 , and also lower quantities of $\mathrm{Al}, \mathrm{Mg}$, and $\mathrm{K}$. Comparatively, AAS and GP-AAS matrix have much lower $\mathrm{Ca} / \mathrm{Si}$ molar ratios, respectively, equal to 0.7 and 0.3 .

Line scans (SEM-EDX) have been performed from a GGBFS particle to the binding matrix for GP-AAS, AAS, and PC samples, with the purpose to study the evolution of $\mathrm{Si}, \mathrm{Ca}, \mathrm{Al}, \mathrm{Mg}$, and $\mathrm{K}$ concentrations through the grain-matrix interface. These data are shown, respectively, in Figs. 6-8. The amount of $\mathrm{K}$ is

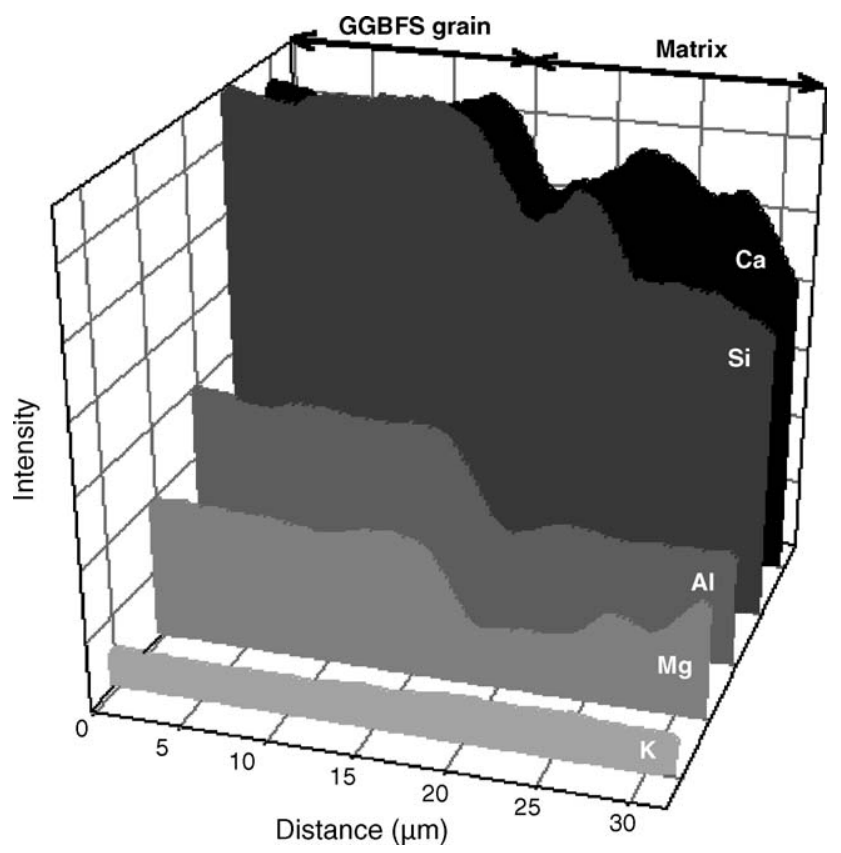

Fig. 8. SEM/EDX line scans from a GGBFS grain to the binding matrix in PC sample. 
very low in all the three GGBFS grains; it increases a little in the GP-AAS matrix and much more in the AAS matrix; on the other hand, it remains constant in the $\mathrm{PC}$ matrix in relation to the alkalinity of the pastes: AAS > GP-AAS > PC. For GP-AAS and AAS samples, $\mathrm{Mg}$ and $\mathrm{Ca}$ decrease progressively from the grain to the matrix where they are found in non-negligible quantities, as a result of slag dissolution. In PC line scan, all the elements concentrations (except for $\mathrm{K}$ ) diminish from slag grain to the matrix where some fluctuations are detectable, probably due to the heterogeneous character of the PC matrix.

In any of the three materials, no distinct phase with a particular composition is formed on the slag particles surface. No specific compound can be identified at the GGBFS grain-matrix interface by means of EDX line scan.

\section{Conclusions}

Four different types of cementitious materials have been synthesised in order to perform a complete and detailed comparison about their composition, crystallographic structure, and microstructure. These are an ordinary Portland cement (PC) sample, an alkali-activated slag (AAS) sample, a geopolymer (GP) sample, and finally a sample containing both alkaliactivated slag phases and geopolymer phases (GP-AAS). For the first time, these different inorganic binders have been extensively studied to highlight differences and similarities in their (micro)-structure.

$\mathrm{X}$-ray diffraction has shown that $\mathrm{PC}$ sample contains $\mathrm{C}-\mathrm{S}-\mathrm{H}$ gel phase, ettringite, portlandite, and quartz. On the contrary, absolutely no crystalline or semi-crystalline phase is formed in GP, GP-AAS, and AAS samples. These are more amorphous than the $\mathrm{C}-\mathrm{S}-\mathrm{H}$ gel phase in Portland cement.

The four cementitious materials show analogous absorption bands in their infrared spectra even if differences are observed. Only the PC spectrum displays sharp bands corresponding to portlandite and ettringite. All samples except for GP sample contain carbonate species, which points out a greater resistance of geopolymers to carbonation. From PC sample to GP sample, the large $\mathrm{Si}-\mathrm{O}$ stretching band (near $1000 \mathrm{~cm}^{-1}$ ) shifts progressively to greater wavenumbers, which indicates an increase of the $\mathrm{SiO}_{4}$ tetrahedra polymerisation. GP and GP-AAS samples contain most likely six-membered alumino-silicate rings in their structure while AAS sample is composed of three-membered rings. On the contrary, no ring was observed in the structure of PC sample.

${ }^{27}$ Al MAS-NMR spectroscopy has shown progressive structural changes from PC sample to GP sample. There is an increase of the $\mathrm{Al}(\mathrm{IV})$ content and a subsequent decrease for $\mathrm{Al}(\mathrm{VI})$; and especially a shift of the Al(IV) peak to lower chemical shifts, which indicates a polymerisation extent of the (alumino)-silicate framework (from $\mathrm{AlQ}^{2}(2 \mathrm{Si})$ to $\mathrm{AlQ}^{4}(4 \mathrm{Si})$ ). ${ }^{27} \mathrm{Al}$ spectrum of $\mathrm{PC}$ sample has also confirmed the presence of ettringite and the incorporation of $\mathrm{Al}(\mathrm{IV})$ in $\mathrm{C}-\mathrm{S}-\mathrm{H}$ gel. The spectrum of AAS sample has detected the presence of $\mathrm{Al}(\mathrm{VI})$ arising probably from a hydration product of AAS such as $(\mathrm{C}, \mathrm{M})_{4} \mathrm{AH}_{13}$ or a $\mathrm{Mg}-\mathrm{Al}$ rich phase, similar to hydrotalcite.
${ }^{29}$ Si MAS-NMR spectroscopy has confirmed previous results obtained by IR and ${ }^{27} \mathrm{Al}$ MAS-NMR spectroscopies: there is a progressive polymerisation extent of the silicate network from Portland cement to alkali-activated slag cement, and further to geopolymers. In Portland cement, $\mathrm{C}-\mathrm{S}-\mathrm{H}$ gel contains silicate groups organised in linear finite chains of "dreierketten" structure, thus mainly $\mathrm{SiQ}^{1}$ and $\mathrm{SiQ}^{2}$ species. In alkali-activated slag cement, $\mathrm{C}-\mathrm{S}-\mathrm{H}$ gel is formed by longer chains in view of the predominance of chain mid-member units, $\mathrm{SiQ}^{2}$ and $\mathrm{SiQ}^{2}(1 \mathrm{Al})$. Geopolymer materials are characterised by a highly polymerised aluminosilicate structure composed mainly of three-dimensional cross-linked units, $\mathrm{SiQ}^{4}(2 \mathrm{Al})$ and $\mathrm{SiQ}^{4}(3 \mathrm{Al})$.

The elemental compositions and the microstructures of the four types of cement have been analysed by means of SEMEDX. Geopolymer sample appears as a homogeneous material while the other samples are composite materials composed of GGBFS particles surrounded by a binding matrix. Absolutely no crack is observed in geopolymer materials contrary to alkali-activated slag and to Portland cement. Portland cement matrix appears more heterogeneous than the three others, the former having a vitreous aspect and a very constant chemical composition. AAS matrix and GP-AAS matrix have lower $\mathrm{Ca} / \mathrm{Si}$ molar ratios $(0.7$ and 0.3 , respectively) than $\mathrm{PC}$ matrix (1.7), which is consistent with their longer or more polymerised (alumino)-silicate chains. Line scans-EDX analyses have shown the absence of any distinct phase with a specific chemical composition at the matrix-particle interfaces and have confirmed the partial dissolution of the slag grains, involved in the formation of the binding phase.

\section{Acknowledgment}

This work has been financially supported by the Construction Steel Design Centre (ARCELOR INNOVATION, Liège) in Belgium, which also provides raw materials and synthesis facilities. The preparation and the characterizations were part of the doctorate thesis of I. Lecomte, who thanks the FRIA (Fonds pour la Formation à la Recherche dans l'Industrie et dans l'Agriculture) for supplying a grant. ${ }^{29} \mathrm{Si}$ and ${ }^{27} \mathrm{Al}$ solidstate MAS-NMR measurements were performed by Professor J. Grandjean (University of Liège).

\section{References}

1. Taylor, H. F. W., Cement Chemistry. Academic Press, London (United Kingdom), 1990.

2. Fernandez-Jimenez, A. and Puertas, F., Structure of calcium silicate hydrates formed in alkaline-activated slag: influence of the type of alkaline activator. J. Am. Ceram. Soc., 2003, 86, 1389.

3. Schneider, J., Cincotto, M. A. and Panepucci, H., ${ }^{29} \mathrm{Si}$ and ${ }^{27} \mathrm{Al}$ highresolution NMR characterization of calcium silicate hydrate phases in activated blast-furnace slag pastes. Cem. Concr. Res., 2001, 31, 993.

4. Richardson, I. G., Brough, A. R., Groves, G. W. and Dobson, C. M., The characterization of hardened alkali-activated blast-furnace slag pastes and the nature of the calcium silicate hydrate $(\mathrm{C}-\mathrm{S}-\mathrm{H})$ phase. Cem. Concr. Res., 1994, 24, 813.

5. Puertas, F., Fernandez-Jimenez, A. and Blanco-Varela, M. T., Pore solution in alkali-activated slag cement pastes. Relation to the composition 
and structure of calcium silicate hydrate. Cem. Concr. Res., 2004, 34, 139.

6. Wang, S.-D. and Scrivener, K. L., Hydration products of alkali activated slag cement. Cem. Concr. Res., 1995, 25, 561.

7. Wang, S.-D. and Scrivener, K. L., ${ }^{29} \mathrm{Si}$ and ${ }^{27} \mathrm{Al} \mathrm{NMR}$ study of alkaliactivated slag. Cem. Concr. Res., 2003, 33, 769.

8. Lecomte, I., Liégeois, M., Rulmont, A., Cloots, R. and Maseri, F., Synthesis and characterization of new inorganic polymeric composites based on kaolin or white clay and on ground-granulated blast furnace slag. $J$. Mater. Res., 2003, 18, 2571.

9. Davidovits, J., Chemistry of geopolymeric systems, terminology. In Géopolymère '99 Proceedings, Saint-Quentin, France, 1999, p. 9.

10. Barbosa, V. F. F., Mackensie, K. J. D. and Thaumaturgo, C., Synthesis and characterisation of materials based on inorganic polymers of alumina and silica: sodium polysialate polymers. Int. J. Inorg. Mater, 2000, 2, 309.

11. Taylor, H. F. W., Proposed structure for calcium silicate hydrate gel. $J$. Am. Ceram. Soc., 1986, 69, 464

12. Lequeux, N., Morau, A., Philippot, S. and Boch, P., Extended X-ray absorption fine structure investigation of calcium silicate hydrates. J. Am. Ceram. Soc., 1999, 82, 1299.

13. Cong, X. and Kirkpatrick, R. J., ${ }^{29}$ Si MAS NMR study of the structure of calcium silicate hydrate. Adv. Cem. Bas. Mater., 1996, 3, 144.

15. Yu, P., Kirkpatrick, R. J., Poe, B., McMillan, P. F. and Cong, X., Structure of calcium silicate hydrate $(\mathrm{C}-\mathrm{S}-\mathrm{H})$ : near-, mid-, and far-infrared spectroscopy. J. Am. Ceram. Soc., 1999, 82, 742.

16. Mollah, M. Y. A., Lu, F. and Cocke, D. L., An X-ray diffraction (XRD) and Fourier transform infrared spectroscopic (FT-IR) characterization of the speciation of arsenic(V) in Portland cement type-V. Sci. Total Environ., 1998, 224, 57.
17. Hanna, R. A., Barrie, P. J., Cheeseman, C. R., Hills, C. D., Buchler, P. M. and Perry, R., Solid state ${ }^{29} \mathrm{Si}$ and ${ }^{27} \mathrm{Al}$ NMR and FTIR study of cement pastes containing industrial wastes and organics. Cem. Concr. Res., 1995, 25, 1435.

18. Clayden, N. J., Esposito, S., Aronne, A. and Pernice, P., Solid state ${ }^{27} \mathrm{Al}$ NMR and FTIR study of lanthanum aluminosilicate glasses. J. Non-Cryst. Solids, 1999, 258, 11.

19. Handke, M. and Mozgawa, W., Vibrational spectroscopy of the amorphous silicates. Vib. Spectrosc., 1993, 5, 75.

20. Sitarz, M., Handke, M. and Mozgawa, W., Identification of silicooxygen rings in $\mathrm{SiO}_{2}$ based on IR spectra. Spectrochim. Acta Part A, 2000, 56, 1819 .

21. Swainson, I. P., Dove, M. T. and Palmer, D. C., Infrared and Raman spectroscopy studies of the $\alpha-\beta$ phase transition in cristobalite. Phys. Chem. Miner, 2003, 30, 353.

22. Lippmaa, E., Samoson, A. and Mägi, M., High-resolution ${ }^{27}$ Al NMR of aluminosilicates. J. Am. Chem. Soc., 1986, 108, 1730.

23. Thomas, J. M. and Klinowski, J., The study of aluminosilicate and related catalysts by high-resolution solid-state NMR spectroscopy. Adv. Catal., 1985, 33, 199.

24. Andersen, M. D., Jakobsen, H. J. and Skibsted, J., Incorporation of aluminium in the calcium silicate hydrate $(\mathrm{C}-\mathrm{S}-\mathrm{H})$ of hydrated Portland cements: A high-field ${ }^{27} \mathrm{Al}$ and ${ }^{29} \mathrm{Si}$ MAS NMR investigation. Inorg. Chem., 2003, 42, 2280.

25. Skibsted, J., Henderson, E. and Jakobsen, H. J., Characterization of calcium aluminate phases in cements by ${ }^{27} \mathrm{Al}$ MAS NMR spectroscopy. Inorg. Chem., 1993, 32, 1013.

26. Richardson, I. G., Brough, A. R., Brydson, R., Groves, G. W. and Dobson, C. M., Location of aluminium in substituted calcium silicate hydrate $(\mathrm{C}-\mathrm{S}-\mathrm{H})$ gels as determined by ${ }^{29} \mathrm{Si}$ and ${ }^{27} \mathrm{Al} \mathrm{NMR}$ and EELS. J. Am. Ceram. Soc., 1993, 76, 2285. 